\title{
THE WISDOM OF THE WISE: \\ The PRESENCE AND FunCTION OF SCRIPTURE \\ IN 1 COR. 1:18-3:231
}

\section{H.H. Drake Williams, III}

Paul's Jewish background and his use of Scripture have been enduring interests within New Testament scholarship. This thesis contributes to the greater discussion of these issues by examining the presence and function of Old Testament Scripture in 1 Corinthians 1:18-3:23.

The first chapter suggests why this is a passage that needed further examination in relation to these two issues. Whereas others have addressed 1 Corinthians 1:18-3:23 in the light of Paul's GraecoRoman opponents and others have considered various types of false teaching in Corinth that consequently shaped Paul's writing, the examination of Scripture in this passage deserved further attention. Others who had addressed Scripture in 1 Corinthians 1:18-3:23 had focused primarily on the citations within the passage and the form in which they were presented. More attention needed to be paid to the presence of implicit references in the forms of allusions and echoes.

Attention also needed to be paid to the function of these Scripture texts, which concerns the second chapter. A variety of questions had to be considered such as the following: does Paul honour the context of a Scripture citation? Does early Jewish literature influence the Scripture that he uses? Does he have a particular hermeneutical presupposition that causes him to use Scripture in a certain way? Questions such as these were initially addressed in this thesis by considering Paul's identity as a firstcentury Jewish writer, an Old Testament type of prophet, and an apostle. In other words, the starting point for determining the function that Scripture plays in 1 Corinthians 1:18-3:23 was based upon Paul's identity.

1 H.H. Drake Williams, The Wisdom of the Wise: The Presence and Function of Scripture in 1 Cor. 1:18-3:23 (unpublished Ph.D. thesis, University of Aberdeen, 1999); supervisor Dr Brian S. Rosner. 
Following a review of Paul's Jewish background, certain starting points could be established concerning his use of Scripture. As a first-century Jewish writer, Paul treated Scripture with great care, as did his contemporaries. He also considered Scripture in relation to early Jewish interpretation of similar ideas. As a result of Paul's Jewish background, the subsequent study throughout 1 Corinthians 1:18-3:23 examines the presence of the Scripture text that Paul used to formulate his thinking in relation to similar ideas within early Jewish literature.

It was more difficult to establish a starting point for Paul's interpretation of Scripture in relation to its context, however. Early Jewish writers did not seem to have any hard and fast rule that could be stated regarding the respect or lack of respect for context. Numerous scholars had suggested how Paul's Christian experience caused him to see Scripture in a variety of ways. Some saw the influence of the Spirit in his interpretative practices. Others saw his Christian experience, his Christological reflections, or his ecclesiological ideas influencing his use of Scripture. Others saw the new time era in which he lives influencing his use of Scripture.

From all of these scholarly opinions, this thesis decided to proceed by examining the context of a particular Scripture text in full before determining the factors that may have influenced Paul's use of a particular text. As a prophet and as an apostle, the practices of typology, corporate representation, and the new time era in Christ are likely to have some effect on his writing. These, however, were considered following a study of each Scripture text's context.

The thesis proceeds in a rather step-like manner from this point. Each chapter (3-10) begins with a determination of Scripture that is present within it. It establishes the presence of a citation first, then an allusion, and then an echo since this is the order in which they are most recognisable. It then proceeds to examine the context of each Scripture text within the passage. It then looks at each subsection of 1 Corinthians 1:18-3:23 to see in what ways the Scripture context and early Jewish interpretations of Scriptural ideas play a role in Paul's thinking. It also considers at points whether prophetic and apostolic interpretations of a Scripture text could have been used.

A number of conclusions were drawn as a result of this approach. Firstly, the presence of Scripture is more evident within this portion of Paul's writing than has hitherto been realised. Isaiah 29:14 in 1 Corinthians 1:19, Jeremiah 9:23 [24] in 1:31, Job 5:13 in 3:19, and Psalm 94:11 [93:11] in 3:20 should all be considered citations. It 
affirms that Isaiah $40: 13$ is a citation in 2:16 when an author's perspective is considered, but it indicates that it may be perceived differently from a Corinthian reader's perspective. The thesis also asserts that Isaiah 64:3 [64:4] is what is most likely cited within 2:9. The study proposes the presence of two allusions: Jeremiah 9:22 [23] in 1:26-29 and Isaiah 65:17 in 2:9. Finally, it contends that six Scriptural echoes play a role in Paul's argument in this passage: Isaiah 33:18 in 1:20, Isaiah 28:16 in 1:21-24, Zechariah 4:6 in 2:3-5, Daniel 2:19-23 in 2:6-8, 10-11, Isaiah 5:1-7 in 3:6-9, Isaiah 3:3 in 3:10, and Malachi 3:2-3 in 3:12-15. As a result, this work contends that Paul used Scripture consciously or unconsciously to communicate a significant portion of his argument.

Secondly, this thesis concludes that Paul's use of Scripture within this section of his writing agrees with its original context and stands in line with a majority of early Jewish tradition. It also concludes that Paul interprets Scripture in relation to the new time era in which he lives as an apostle. It indicates that some prophetic interpretative practices may be seen in some portions of 1 Corinthians 1:18-3:23 as well.

Finally, when the presence and function of Scripture are considered throughout 1:18-3:23, they provide assistance in understanding Paul and a difficult portion of his writing. Individual chapters suggest how Paul's use of Scripture can aid in the understanding of Paul's concern about issues such as wisdom, division, Christian calling, boasting, his weakness, the Corinthian infants in Christ, and the role of Christian workers. Understanding the difficult section of 1:18-3:23 thus is aided by using the presence of Scripture as a helpful guide for interpretation. 